\title{
Thermotolerant Zymomonas mobilis: Comparison of Ethanol Fermenta- tion Capability with that of an Efficient Type Strain
}

\author{
Kaewta Sootsuwan ${ }^{1}$, Akira Irie ${ }^{2}$, Masayuki Murata ${ }^{2}$, Noppon Lertwattanasakul ${ }^{1}$, Pornthap Tha- \\ nonkeo $^{3}$ and Mamoru Yamada ${ }^{*, 1,2}$ \\ ${ }^{I}$ Department of Biological Chemistry, Faculty of Agriculture, Yamaguchi University, Yamaguchi 753-8515, Japan \\ ${ }^{2}$ Applied Molecular Bioscience, Graduate School of Medicine, Yamaguchi University, Ube 755-8505, Japan \\ ${ }^{3}$ Department of Biotechnology, Faculty of Technology, Khon Kaen University, Khon Kaen 40002, Thailand
}

\begin{abstract}
Zymomonas mobilis is an alternative microorganism to Saccharomyces cerevisiae for ethanol production. To find a thermotolerant $Z$. mobilis strain, the growth and ethanol production of four isolates in Thailand were compared with those of the efficient strain ZM4 (NRRL B-14023) at different temperatures. One of the selected strains, TISTR 405, was found to grow and produce ethanol even at $39^{\circ} \mathrm{C}$ to an extent similar to that at $30^{\circ} \mathrm{C}$, and the growth and ethanol productivity at $39^{\circ} \mathrm{C}$ were better than those of ZM4 at $30^{\circ} \mathrm{C}$, suggesting that TISTR 405 is suitable for ethanol fermentation at high temperatures. Analysis of genes directly related to ethanol formation or degradation, $a d h A, a d h B$ and $p d c$, encoding alcohol dehydrogenase (Adh) A, AdhB and pyruvate decarboxylase, respectively, revealed that these genes were highly conserved in both strains. Comparison of their gene expression and activity of the products in both TISTR 405 and ZM4 at different temperatures or growth phases indicated that there was not a great difference at the transcriptional level, but the total activity of AdhA and AdhB in TISTR 405 was higher than that in ZM4. Both strains showed a significant increase in AdhB activity in the stationary phase.
\end{abstract}

Keywords: Thermotolerant, Zymomonas mobilis, ethanol production.

\section{INTRODUCTION}

Unlike mesophilic microorganisms, the use of thermotolerant microorganisms enables fermentation to be performed at high temperatures, which may have several advantages: a) reduction in cost for cooling fermentation units, which maintain optimal conditions for the fermentation reaction, b) reduction in contamination of mesophilic microorganisms, c) increase in the speed of catalytic reactions related to fermentation, for example, saccharification of starch for ethanol fermentation, and d) thereby, reduction in total costs including costs of facilities or labor. The Gram-negative and facultative anaerobe Zymomonas mobilis is known to be a potent ethanol producer [1], but no thermotolerant strain of the organism that is thought to be beneficial for ethanol fermentation at high temperatures has been reported.

In Z. mobilis, the ethanol production route from glucose, which consists of the Entner-Doudoroff (ED), glyceraldehyde-3-phosphate-to-pyruvate (GP) and pyruvate-to-ethanol (PE) pathways, provides most of the ATP required for cell activities, about one mole of ATP per mole of glucose [2,3], a much lower level than that in Saccharomyces cerevisiae, the traditional ethanol producer. The organism thus appears to maintain a high level of glucose flux through the pathways to compensate its low ATP yield [4], for which large amounts of enzymes related to the pathways are expressed, constituting $30-50 \%$ of total soluble proteins of cells [3]. As a consequence, it performs less biomass formation and

*Address correspondence to this author at the Department of Biological Chemistry, Faculty of Agriculture, Yamaguchi University, Yamaguchi 7538515, Japan; E-mail: m-yamada@yamaguchi-u.ac.jp efficient production of ethanol compared to $S$. cerevisiae [1]. Z. mobilis, which has a relatively compact genome with a small number of genes, about 2,000, possesses incomplete Embden-Meyerhof-Parnas pathway and incomplete TCA cycle due to a lack of genes for 6-phosphofructokinase, 2oxoglutarate dehydrogenase complex and malate dehydrogenase [3-5] but possesses strong activities of ED-GP pathways [6]. Therefore, it has been thought that Z. mobilis is one of the promising microorganisms for fermentative production of various materials from pyruvate or other intermediates.

Many experiments on ethanol production by using $Z$. mobilis or by introducing its genes into other bacteria have been carried out [7-10], but ethanol production at high temperatures has not been attempted yet. We previously found that magnesium and sugar alcohols protected Z. mobilis from heat stress and promoted cell growth and ethanol production at high temperatures [11]. In this study, we selected and characterized relatively thermotolerant $Z$. mobilis strains from isolates in Thailand. The genes directly related to ethanol fermentation and their expressions in one of the strains at $30-37^{\circ} \mathrm{C}$ were compared with those of an efficient strain for ethanol production. We also discussed the regulation of expression of the genes.

\section{MATERIALS AND METHODS}

\section{Materials}

Restriction enzymes and T4 DNA ligase were purchased from Takara Shuzo (Kyoto, Japan) and New England Biolabs (Beverly, MA). A DNA sequencing kit (ABI PRISMP ${ }^{\circledR}$ BigDye $^{\circledR}$ Terminator v3.1 Cycle Sequencing Kit) was purchased from Applied Biosystems Japan. Oligonucleotide 
primers were synthesized by Proligo Japan K. K. (Tokyo, Japan). Alcohol dehydrogenase (Adh) purified from Gluconobacter suboxydans IFO 12528 [12] was used for determination of the concentration of ethanol produced. All other chemicals were of analytical grade and obtained from commercial sources.

\section{Bacterial Strains and Culture Conditions}

Z. mobilis strains, TISTR 405, TISTR 548, TISTR 550 and TISTR 551, were obtained from the TISTR Culture Collection Bangkok MIRCEN, and ZM4 (NRRL B-14023) was provided by E. Yanase. These strains were cultivated in YPD medium consisting of $0.3 \%(\mathrm{w} / \mathrm{v})$ yeast extract, $0.5 \%(\mathrm{w} / \mathrm{v})$ peptone and $3 \%(\mathrm{w} / \mathrm{v})$ glucose [13] at the temperature indicated with a shaking speed of $100 \mathrm{rpm}$ [14]. Cells were harvested and suspended in $10 \mathrm{mM}$ phosphate buffer $(\mathrm{pH} 7.0)$ and then passed twice through a French press at 16,000 psi, followed by a low-speed centrifugation for removing unbroken cells, then centrifuged at $86,000 \mathrm{~g}$ for $90 \mathrm{~min}$. The supernatant was used as a soluble fraction. E. coli was grown in LB medium consisting of $1 \%(\mathrm{w} / \mathrm{v})$ Bactotryptone, $0.5 \%$ $(\mathrm{w} / \mathrm{v})$ yeast extract and $0.5 \%(\mathrm{w} / \mathrm{v}) \mathrm{NaCl}$. Fifty $\mu \mathrm{g}$ of ampicillin per $\mathrm{ml}$ was added to the medium if necessary.

\section{Cloning and Analysis of $\boldsymbol{a d h}$ and $p d c$ Genes}

Conventional recombinant DNA techniques were applied [15]. The genomic DNA of Z. mobilis was prepared by the standard method [15]. The $a d h$ and $p d c$ genes including about $500 \mathrm{bp}$ upstream from the initiation codon and coding region from $Z$. mobilis were cloned after PCR amplification using primers (Table 1) and the genomic DNA as a template. The specific primer sets for $a d h A, a d h B$ and $p d c$ were designated according to the nucleotide sequences of the genomic sequence of Z. mobilis ZM4. Each amplified DNA fragment was inserted into the multi-cloning site of pUC119 and then subjected to nucleotide sequencing [16]. PCR was performed on Takara PCR thermal cycler MP (Takara Biomedicals, Japan). Nucleotide sequencing was analyzed by using ABI PRISM $^{\text {TM }} 310$ Genetic analyzer (The Perkin-Elmer Corp., USA). Primers used for the sequencing are M13 universal primers and also listed in Table $\mathbf{1}$. The determined nucleotide sequences were deposited in DDBJ and the accession numbers are AB359061, AB359062 and AB359063 for adhA, $a d h B$ and $p d c$, respectively.

\section{RT-PCR Analysis}

Cells were grown at $30^{\circ} \mathrm{C}$ or $37^{\circ} \mathrm{C}$ in YPD medium until exponential $(8 \mathrm{~h})$ and stationary $(20 \mathrm{~h})$ phases, and then subjected to RNA isolation. For determining the effect of glucose, glycerol or ethanol on the expression of the three genes, cells were first grown for $14 \mathrm{~h}$ at $37^{\circ} \mathrm{C}$ in YPD medium, washed twice with YP medium, transferred to YPD, YPG and YPE medium containing 3\% (w/v) glucose, 3\% $(\mathrm{w} / \mathrm{v})$ glycerol and $2 \%(\mathrm{v} / \mathrm{v})$ ethanol, respectively, and further incubated for $2 \mathrm{~h}$ at $37^{\circ} \mathrm{C}$. Total RNA from the cells was isolated by the hot phenol method [17]. The concentration of RNA was estimated spectrophotometrically at $260 \mathrm{~nm}$. RTPCR analysis was performed using an mRNA Selective RTPCR Kit (Takara Shuzo, Kyoto Japan) with $0.1 \mu \mathrm{g}$ of total RNA as a template and primer sets. For detection of $16 \mathrm{~S}$ rRNA, $0.001 \mu \mathrm{g}$ of total RNA was used as a template. RTPCR was performed on Takara PCR thermal cycler MP (Takara Biomedicals, Japan). After RT reaction had been performed at $40^{\circ} \mathrm{C}$ for $15 \mathrm{~min}$, PCR consisting of denaturing at $82^{\circ} \mathrm{C}$ for $1 \mathrm{~min}$, annealing at a fixed temperature, 5 degrees lower than $T_{m}$, which was calculated by the rule of thumb

Table 1. Primers Used in this Study

\begin{tabular}{|c|c|c|}
\hline Name & Sequences & Usage \\
\hline AdhA-F & $5^{\prime}$-ACACTGCAGAAGCATAGCCGGACATCATACC-3' & Cloning of $a d h A$ gene \\
\hline AdhA-R & $5^{\prime}$-CTCGAATTCCCGTTTATGCTTCCGCCTTCAC-3' & Cloning of $a d h A$ gene \\
\hline AdhB-F & $5^{\prime}$-ACAGTCGACGAGGAAAGCCTGATCTGCCATT-3' & Cloning of $a d h B$ gene \\
\hline AdhB-R & 5' -CGCGAATTCGCCGGTGTCTTGATCTTGTCTA-3' & Cloning of $a d h B$ gene \\
\hline Pdc-F & $5^{\prime}$-AGAGCATGCGGCTTTGTCAGTGTTGCGGTAT-3' & Cloning of $p d c$ gene \\
\hline Pdc-R & $5^{\prime}$-ACTGAATTCAAAAGCCCGCCCGGTAAAACCG-3' & Cloning of $p d c$ gene \\
\hline AdhART-F & $5^{\prime}-$ CATGAAAGCAGCCGTCA-3' & RT-PCR and sequencing of $a d h A$ gene \\
\hline AdhART-R & $5^{\prime}-$ TACACCCGCGCAAGTGA-3' & RT-PCR and sequencing of $a d h A$ gene \\
\hline AdhBRT-F & $5^{\prime}$-GTCAACGAAATGGGCGA-3' & RT-PCR and sequencing of $a d h B$ gene \\
\hline AdhBRT-R & $5^{\prime}-$ GTGACGGTCAACAATGG-3' & RT-PCR and sequencing of $a d h B$ gene \\
\hline PdcRT-F & $5^{\prime}$-GACTACAACCTCGTCCT-3' & RT-PCR and sequencing of $p d c$ gene \\
\hline PdcRT-R & $5^{\prime}$-CAGGGCATGGGAGCAAT-3' & RT-PCR and sequencing of $p d c$ gene \\
\hline M4 & $5^{\prime}-\mathrm{GTTTTCCCAGTCACGAC-3{ } ^ { \prime }}$ & Sequencing of all 3 genes \\
\hline RV & $5^{\prime}-\mathrm{CAGGAAACAGCTATGAC}-3^{\prime}$ & Sequencing of all 3 genes \\
\hline AdhA-S & $5^{\prime}-$ TCGCCGTTGGTCTGCCTCCT-3' & Sequencing of $a d h A$ gene \\
\hline AdhB-S & $5^{\prime}$-TATCGAGACCCATAGCAACA-3' & Sequencing of $a d h B$ gene \\
\hline Pdc-S & $5^{\prime}$-AATTCATCGCCAACCGCGAC-3' & Sequencing of $p d c$ gene \\
\hline
\end{tabular}


method [18], for $1 \mathrm{~min}$ and extension at $72^{\circ} \mathrm{C}$ for $1 \mathrm{~min}$ was carried out using the two primers for each gene. The PCR products after 20,25, 30 and 35 cycles for each gene were analyzed by $0.9 \%$ agarose gel electrophoresis, and the relative intensity of the products was densitometrically estimated by using a Bio-Rad molecular imager $[19,20]$. Under our conditions, the RNA-selective RT-PCR was able to specifically detect mRNA, because no band was observed when reverse transcriptase was omitted.

\section{Comparison of Nucleotide Sequences}

Published nucleotide sequences were obtained from the DDBJ database. Comparison and alignment of nucleotide sequences were conducted by using GENETYX (Software Development, Tokyo, Japan).

\section{Analytical Procedures and Enzyme Assays}

Alcohol concentration in the medium was measured by an enzymatic method (ferricyanide reductase activity) with purified G. suboxydans Adh [12]. Protein content was determined by the Dulley and Grieve method [21] using bovine serum albumin as a standard. Adh activity was determined by measuring the alcohol-dependent reduction of $\mathrm{NAD}^{+}$using ethanol or butanol as described previously [22]. One unit of activity is defined as $\mu$ mole of NADH formed per minute per $\mathrm{mg}$ of proteins. For detection of Adh activity by staining, soluble fraction $(100 \mu \mathrm{g}$ of proteins) was separated on $7.5 \%$

A

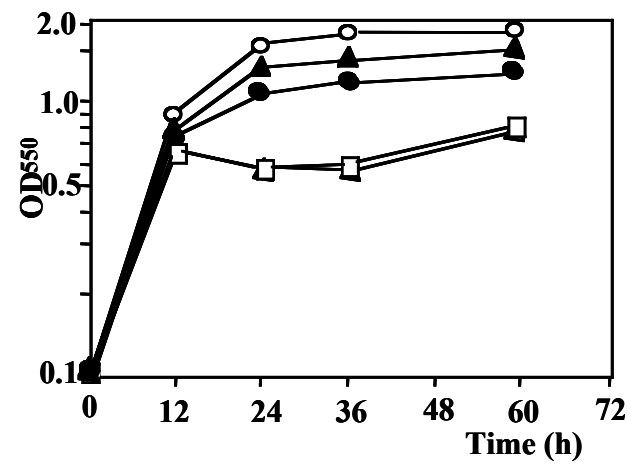

C

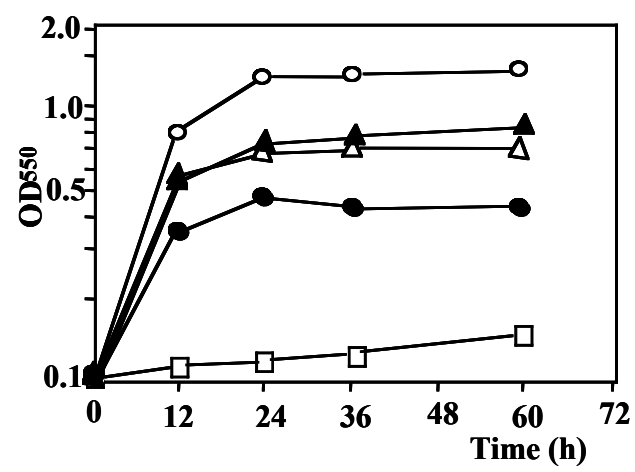

polyacrylamide gel with Tris-glycine buffer ( $\mathrm{pH} 8.5)$. NAD ${ }^{+}$ dependent Adh activity was detected by soaking the gel in a solution containing $100 \mathrm{mM}$ Tris- $\mathrm{HCl}(\mathrm{pH} 8.0), 0.1 \mathrm{mM}$ $\mathrm{NAD}^{+}, 0.1 \mathrm{M}$ ethanol or butanol, $0.2 \mathrm{mM}$ nitroblue tetrazolium (NBT) and $0.2 \mathrm{mM}$ phenazine methosulfate. After incubation in the dark at $25^{\circ} \mathrm{C}$ for $2-5 \mathrm{~min}$, the reaction was stopped by transferring the gel into $7 \%$ acetic acid solution [23]. NADH-dependent Adh activity was detected as described previously [24] under UV light by using NADH as a cofactor. The reduction reaction was performed in $100 \mathrm{mM}$ MES (pH 6.0) with $0.1 \mathrm{M}$ acetaldehyde as a substrate.

\section{RESULTS}

\section{Comparison of Growth and Ethanol Production}

In order to obtain thermotolerant Z. mobilis strains, which are suitable for fermentation at high temperatures, growth at high temperatures of four isolates in Thailand, TISTR 405, TISTR 548, TISTR 550 and TISTR 551, was compared with that of a type strain, ZM4 (NRRL B-14023), which is known to be efficient for ethanol production. When grown in YPD plates at different temperatures from $30^{\circ} \mathrm{C}$ to $40^{\circ} \mathrm{C}$, TISTR 405, TISTR 548 and TISTR 550 grew well at temperatures up to at $39^{\circ} \mathrm{C}$, but the other strains did not. No strains, however, were able to grow well at more than $39^{\circ} \mathrm{C}$. Their abilities for growth and ethanol production in YPD medium were then compared (Fig. 1). TISTR 405 showed the highest optical density at $30^{\circ} \mathrm{C}$ and $39^{\circ} \mathrm{C}$. TISTR 405 and

\section{B}

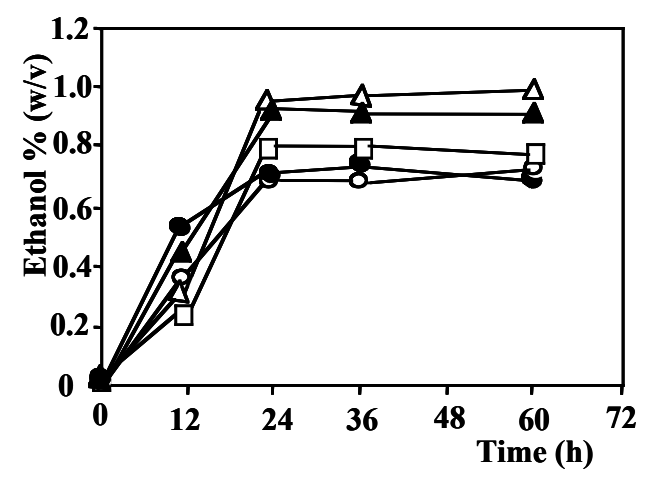

D

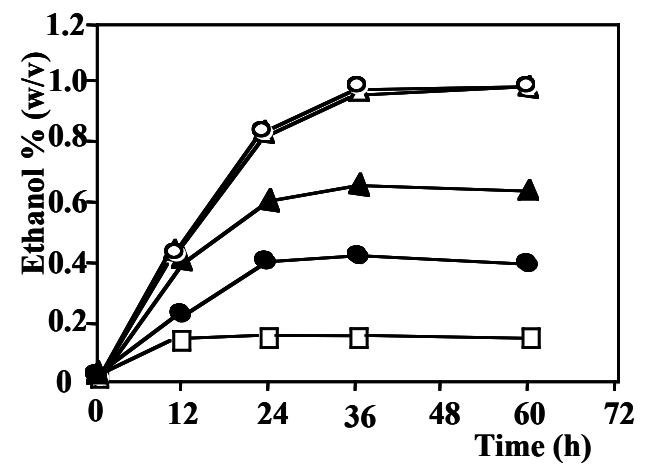

Fig. (1). Comparison of growth and ethanol production of $Z$. mobilis strains from Thailand collection with the efficient type strain at $30^{\circ} \mathrm{C}$ and $39^{\circ} \mathrm{C}$. Z. mobilis TISTR $405(\circ)$, TISTR $550(\Delta)$, TISTR $551(\square)$, TISTR $548(\boldsymbol{\Delta})$ and the type strain ZM4 $(\bullet)$ were grown in YPD medium at $30^{\circ} \mathrm{C}(\mathbf{A})$ or $39^{\circ} \mathrm{C}(\mathbf{C})$ under shaking condition at $100 \mathrm{rpm}$ and the ethanol concentration in the medium at $30^{\circ} \mathrm{C}(\mathbf{B})$ or $39^{\circ} \mathrm{C}(\mathbf{D})$ were measured. The experiments were repeated three times and the patterns were confirmed to be reproducible. Data from one such representative experiment are shown. 
TISTR 550 showed the largest production of ethanol at $39^{\circ} \mathrm{C}$, the levels being more than and nearly equivalent to, respectively, the level at $30^{\circ} \mathrm{C}$. The growth and ethanol production level of both strains at $39^{\circ} \mathrm{C}$ were much higher than those of the efficient strain. Based on these data, we chose TISTR 405 as a thermotolerant strain for further analysis.

Cloning and Characterization of $\operatorname{adh} A, \operatorname{adh} B$ and $p d c$ Genes Directly Related to Ethanol Synthesis or Degradation

To examine the molecular diversity of $a d h A, a d h B$ and $p d c$ genes between the thermotolerant TISTR 405 and the type ZM4 strains, the $a d h A, a d h B$ and $p d c$ genes, each including an approximately 500-bp upstream region, were individually cloned and sequenced. The identities in nucleotide sequence in the coding region and 5'-noncoding region (within 200 bases upstream from the initiation codon) of the three genes are compared in Table 2. All sequences of the coding and 5'-noncoding regions of the three genes shared identities of more than $96 \%$ between the two strains. None of the nucleotide substitutions found in the coding regions of the three genes caused amino acid substitutions; that is, there was complete conservation in primary sequences of AdhA, AdhB and Pdc. Therefore, the three genes directly related to ethanol synthesis or degradation are highly conserved between the two strains. Additionally, since both the coding and 5'-noncoding regions are conserved, these genes are unlikely to be responsible for thermotolerance of TISTR 405.

Table 2. Identity of Nucleotide Sequences of Genes Related to Ethanol Synthesis and Degradation Between $Z$. mobilis Strains and Between $E$. coli Strains

\begin{tabular}{|c|c|c|c|c|c|}
\hline & $\operatorname{adh} A$ & $\operatorname{adh} B$ & $p d c$ & $\operatorname{adh} P^{\mathrm{a}}$ & $y i a Y^{\mathrm{a}}$ \\
\hline \multirow[t]{2}{*}{ Zymomonas mobilis ZM4 } & 100 & 100 & 100 & & \\
\hline & $(100)$ & $(100)$ & $(100)$ & & \\
\hline \multirow[t]{2}{*}{ Zymomonas mobilis TISTR 405} & 99 & 99 & 96 & & \\
\hline & $(100)$ & $(100)$ & $(100)$ & & \\
\hline Escherichia coli $\mathrm{K}-12$ & & & & 100 & 100 \\
\hline MG1655 & & & & $(100)$ & $(100)$ \\
\hline \multirow[t]{2}{*}{ Escherichia coli $\mathrm{K}-12 \mathrm{~W} 3110$} & & & & 100 & 100 \\
\hline & & & & $(100)$ & $(100)$ \\
\hline \multirow[t]{2}{*}{ Escherichia coli 101-1 } & & & & 100 & 97 \\
\hline & & & & $(100)$ & (99) \\
\hline \multirow[t]{2}{*}{ Escherichia coli APEC 01} & & & & 96 & 98 \\
\hline & & & & (99) & (85) \\
\hline Escherichia coli $\mathrm{O} 157: \mathrm{H} 7$ & & & & 98 & 99 \\
\hline EDL933 & & & & (99) & (96) \\
\hline
\end{tabular}

adhP encodes for Adh corresponding to the $Z$. mobilis adhA $(74 \%$ identity in primary sequence between AdhA and AdhP) and yia $Y$ encodes for Adh corresponding to the $Z$. mobilis adhB (75\% identity in primary sequence between AdhB and YiaY). Values and values in parentheses represent percentages of identity of nucleotide sequences in the coding region and the 5'-noncoding region (within 200 bases upstream from the initiation codon), respectively. Comparison and alignment of the sequences were performed with the GENETYX software.

When the conservation of genes related to the ethanol formation or degradation among $E$. coli strains, K-12
MG1566, K-12 W3110, 101-1 and APEC 01, O157: H7 EDL1933 was estimated by comparison of their genomic sequences in databases, adhP encoding Adh corresponding to Z. mobilis adhA showed more than $99 \%$ in the 5 'noncoding regions (in 200 bases upstream from the initiation codon) and more than $97 \%$ in the coding region (Table 2). yia $Y$ encoding Adh corresponding to $Z$. mobilis adhB showed more than $85 \%$ in the 5 '-noncoding region and more than $96 \%$ in the coding region. Therefore, the extent of conservation at the nucleotide sequence level in $a d h A$ and $a d h B$ between the mesophilic and thermotolerant $Z$. mobilis strains seems to be the level in adhP and yiaY between general $E$. coli strains.

\section{Expression of $a d h A, a d h B$ and $p d c$ Genes in Exponential and Stationary Phases at $30^{\circ} \mathrm{C}$ and $37^{\circ} \mathrm{C}$}

To compare the expression of $a d h A, a d h B$ and $p d c$ genes in the thermotolerant strain TISTR 405 and that in the type ZM4 strain, RT-PCR was performed with total RNAs from cells that had been grown in YPD medium at $30^{\circ} \mathrm{C}$ or $37^{\circ} \mathrm{C}$ for $8 \mathrm{~h}$ (exponential phase) and $20 \mathrm{~h}$ (stationary phase) with glucose still remaining and absent, respectively, in the medium (Fig. 2). The effect of temperature was tested at $37^{\circ} \mathrm{C}$ instead of $39^{\circ} \mathrm{C}$ because of the heat sensitivity of the type strain. Band intensities from the $a d h A, a d h B$ and $p d c$ genes in both strains were similar at both exponential and stationary phases at $30^{\circ} \mathrm{C}$ or $37^{\circ} \mathrm{C}$, though there were minor exceptions that the intensity from $p d c$ was reduced 2- to 4-fold and that from $a d h B$ also slightly reduced at the stationary phase compared with those at the exponential phase. In the type strain, more than 4-fold reduced intensity was found in adhA and $p d c$ at the stationary phase at both temperatures. These results suggested that the $a d h A$, and $a d h B$ genes are expressed almost similarly at both exponential and stationary phases at $30^{\circ} \mathrm{C}$ or $37^{\circ} \mathrm{C}$ while $p d c$ gene is slightly reduced in expression at stationary phase and that their expressions in both strains are similar, which is consistent with the high identity of the nucleotide sequences of the genes including the 5 '-noncoding region.

Next, the effect of glucose, glycerol or ethanol on the expression of the three genes was examined at $37^{\circ} \mathrm{C}$ with TISTR 405 (Fig. 3). Total RNAs from the cells grown in YPD medium, then exposed to glucose, glycerol or ethanol were subjected to RT-PCR. Comparison of band intensities revealed that the expression of all three genes in YPG and YPE media were reduced 2- to 4-fold compared with that in YPD medium. Considering the fact that $Z$. mobilis is unable to utilize glycerol or ethanol as a carbon source, these results suggested that none of these genes are induced by ethanol. The relatively high expression levels of these genes in YPD medium might be due to the vegetative growth but not due to the induction by glucose because the effect of glucose was relatively small.

Enzyme Activities of Gene Products of $a d h A, a d h B$ and $p d c$ in Exponential and Stationary Phases at $30^{\circ} \mathrm{C}$ and $37^{\circ} \mathrm{C}$

To further compare the expression of $a d h A$ and $a d h B$ in the thermotolerant strain and that in the type strain, activities of butanol dehydrogenase and ethanol dehydrogenase, which reflect the activity for AdhA and the combined activities for AdhA and AdhB, respectively, were measured with soluble 
fraction from cells grown under the same conditions as those used in the experiments for which results are shown in Fig. (2) (Table 3). At both temperatures, activity levels of butanol and ethanol dehydrogenases from cells of both strains in the stationary phase were found to be higher than those in the exponential phase. Notably, both activity levels in the thermotolerant strain at $30^{\circ} \mathrm{C}$ in the stationary phase and at $37^{\circ} \mathrm{C}$ in both phases were 1.8- to 3.8-fold higher than those of the corresponding samples in the type strain. These significant differences might be related to the thermotolerance of TISTR 405.
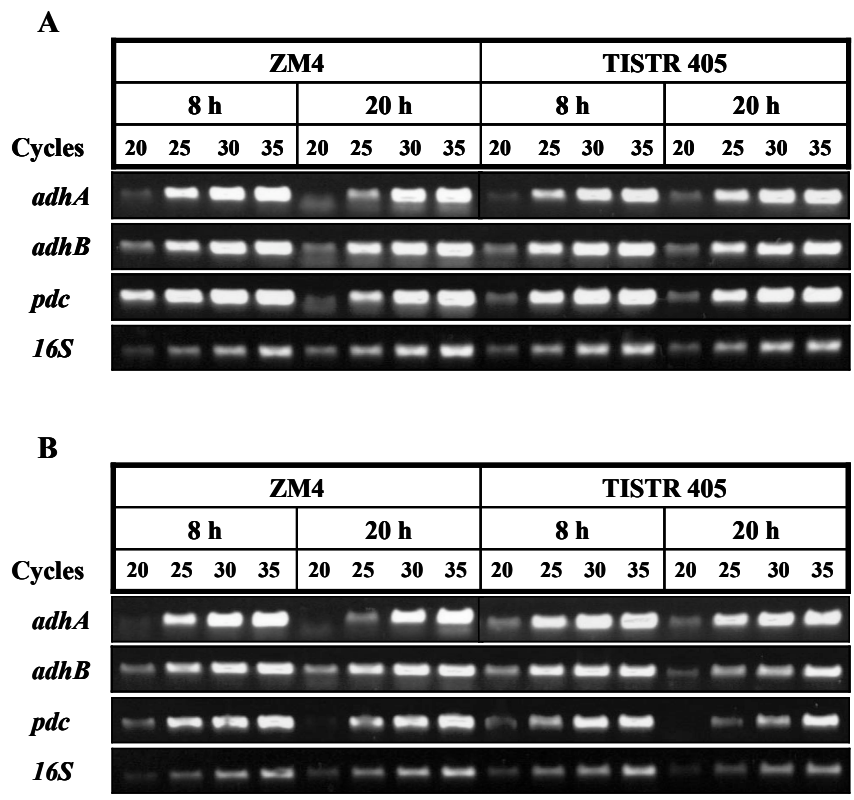

Fig. (2). Expression of $a d h A, a d h B$ and $p d c$ of TISTR 405 and ZM4 at $30^{\circ} \mathrm{C}$ and $37^{\circ} \mathrm{C}$ in YPD medium. Cells were grown in YPD medium at $30^{\circ} \mathrm{C}(\mathbf{A})$ or $37^{\circ} \mathrm{C}(\mathbf{B})$, and total RNAs from the cells at mid-exponential $(8 \mathrm{~h})$ and early stationary $(20 \mathrm{~h})$ phases were subjected to RT-PCR. After RT reaction, PCR was performed 20, 25, 30 and 35 cycles and the products were analyzed by agarose gel electrophoresis. Total RNA used was $0.1 \mu \mathrm{g}$ for detection of the expression of $a d h A, a d h B$ and $p d c$, or $0.001 \mu \mathrm{g}$ for $16 \mathrm{~S}$ rRNA.

\begin{tabular}{|c|c|c|c|c|c|c|c|c|c|c|c|}
\hline \multirow[b]{3}{*}{ Cycles } & \multicolumn{11}{|c|}{ TISTR 405} \\
\hline & \multicolumn{3}{|c|}{ YPD } & \multicolumn{4}{|c|}{ YPG } & \multicolumn{4}{|c|}{ YPE } \\
\hline & 20 & 30 & 35 & 20 & 25 & 30 & 35 & & 25 & 30 & 35 \\
\hline $\operatorname{adh} A$ & \multicolumn{11}{|c|}{ 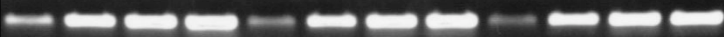 } \\
\hline$a d h B$ & \multicolumn{11}{|c|}{ 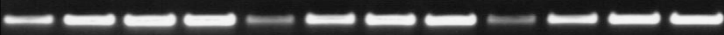 } \\
\hline$p d c$ & \multicolumn{11}{|c|}{ 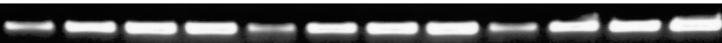 } \\
\hline $16 S$ & +2 & $=$ & - & & 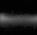 & 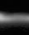 & $=$ & $=$ & $=$ & - & $=$ \\
\hline
\end{tabular}

Fig. (3). Expression of $a d h A, a d h B$ and $p d c$ of TISTR 405 in the presence of glucose, glycerol or ethanol at $37^{\circ} \mathrm{C}$ in YPD medium. Total RNAs and RT-PCR were performed described in Materials and Methods and Fig. (2).

To detect AdhA and AdhB enzymes in samples from both strains, active staining after polyacrylamide gel electrophoresis was carried out with the same preparation of soluble fraction used in Table 3 (Fig. 4). When NBT was used as an electron acceptor, a single band was specifically detected in each sample in the presence of butanol, and one band and two bands were observed in exponential and stationary phases, respectively, in the presence of ethanol. Since the position of the upper band of the ethanol-dependent bands corresponded to that of the butanol-dependent band, the upper and lower bands seem to be derived from AdhA and AdhB, respectively. In the procedure to detect the enzymesubstrate-NADH complex, two bands (strong and weak) in exponential phase and two strong bands in stationary phase were detected in the presence of acetaldehyde and NADH. The intensity of bands in stationary phase was stronger than those in the exponential phase, in agreement with enzyme activities shown in Table 3. Taken together, the results suggested that AdhA are present in both phases at a level corresponding to that of the butanol-dependent activity. On the other hand, the AdhB level appears to be low in the exponential phase compared with that in the stationary phase.

Table 3. Comparison of Adh Activities in the Thermotolerant Strain with those in the Efficient Type Strain

\begin{tabular}{|c|c|c|c|c|}
\hline \multirow{2}{*}{ Strain } & \multirow{2}{*}{$\begin{array}{c}\text { Growth } \\
\text { Temperature }\end{array}$} & \multirow{2}{*}{$\begin{array}{c}\text { Growth } \\
\text { Phase }\end{array}$} & \multicolumn{2}{|c|}{ Adh Activity $(\mathbf{U} / \mathbf{m g})^{\mathbf{a}}$} \\
\cline { 4 - 5 } & & & ButOH & EtOH \\
\hline \hline ZM4 & $30^{\circ} \mathrm{C}$ & Exponential & $0.50 \pm 0.1$ & $1.53 \pm 0.1$ \\
\hline & $30^{\circ} \mathrm{C}$ & Stationary & $0.97 \pm 0.3$ & $2.65 \pm 0.02$ \\
\hline & $37^{\circ} \mathrm{C}$ & Exponential & $0.38 \pm 0.04$ & $1.27 \pm 0.3$ \\
\hline & $37^{\circ} \mathrm{C}$ & Stationary & $1.11 \pm 0.1$ & $2.88 \pm 0.05$ \\
\hline & $30^{\circ} \mathrm{C}$ & Exponential & $0.54 \pm 0.1$ & $1.73 \pm 0.3$ \\
\hline & $30^{\circ} \mathrm{C}$ & Stationary & $1.94 \pm 0.2$ & $5.17 \pm 0.9$ \\
\hline & $37^{\circ} \mathrm{C}$ & Exponential & $1.46 \pm 0.1$ & $3.99 \pm 0.7$ \\
\hline & $37^{\circ} \mathrm{C}$ & Stationary & $2.03 \pm 0.1$ & $5.30 \pm 0.6$ \\
\hline
\end{tabular}

${ }^{a}$ Adh activities were measured using butanol (ButOH) or ethanol (EtOH) as a substrate as described in Materials and Methods. Reported values are the mean $( \pm \mathrm{SD})$ of three independent experiments.

\section{DISCUSSION}

In this study, we attempted to find thermotolerant Z. mobilis strains from the Thailand collection with ability for efficient ethanol production. As expected, relatively thermotolerant strains were found to be present in the collection. Out of strains tested, two strains were thermotolerant and able to grow and produce ethanol at $39^{\circ} \mathrm{C}$ at a level equivalent to that produced at $30^{\circ} \mathrm{C}$, and they showed higher ethanol productivity at $39^{\circ} \mathrm{C}$ than that of the efficient strain ZM4 at $30^{\circ} \mathrm{C}$ (close to the optimum temperature for ZM4). Therefore, both strains can be used for ethanol fermentation at high temperatures.

Nucleotide sequencing revealed that the three genes, $a d h A, a d h B$ and $p d c$, related to ethanol synthesis or degradation are highly conserved in not only the coding region but also in the 5'-noncoding region between one of the thermotolerant strains and the efficient type strain. The conservativeness does not seem to be specific because the degree of identity is similar to those in the corresponding genes of $E$. coli strains. The conservation at the 5'-noncoding region of 


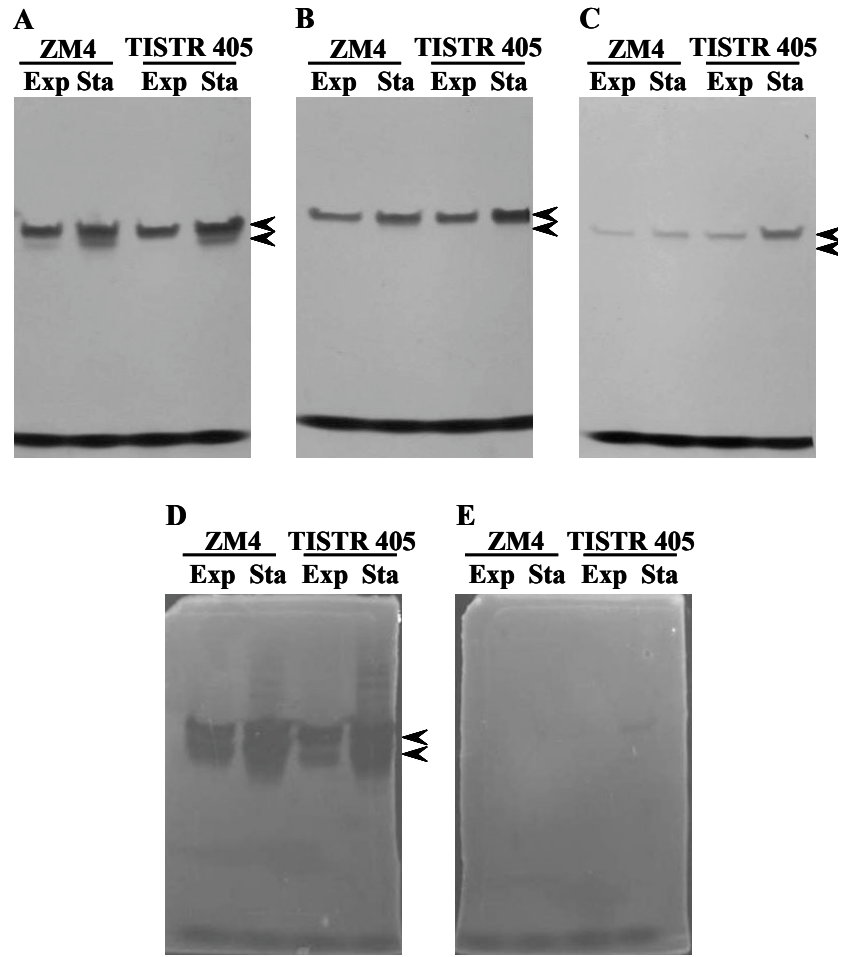

Fig. (4). Detection of AdhA and AdhB activities of TISTR 405 and ZM4. Soluble fractions $(100 \mu \mathrm{g})$ from cells grown in YPD medium at $37^{\circ} \mathrm{C}$ at mid-exponential ( $8 \mathrm{~h}$; Exp) and early stationary $(24 \mathrm{~h}$; Sta) phases were subjected to the active staining using NBT (A, B and $\mathbf{C}$ ) or the detection of NADH-dependent activity under UV (D and $\mathbf{E}$ ) as described in Materials and Methods. The detection was performed in the presence of ethanol and $\operatorname{NAD}^{+}(\mathbf{A})$, butanol and $\mathrm{NAD}^{+}(\mathbf{B}), \mathrm{NAD}^{+}(\mathbf{C})$, acetaldehyde and NADH (D), and NADH (E). Upper and lower arrowheads represent AdhA and AdhB, respectively.

each gene is consistent with the results of RT-PCR, which revealed that the two strains expressed these genes to nearly the same extent at different temperatures or in different growth phases. On the other hand, estimation of AdhA and AdhB activities revealed that both enzyme activities significantly increased in the stationary phase and that at least AdhA activity level of the thermotolerant stain in the exponential phase at $37^{\circ} \mathrm{C}$ was about 3 -fold higher than that at $30^{\circ} \mathrm{C}$. The latter data agree with the finding that the strain showed higher ethanol productivity at $39^{\circ} \mathrm{C}$ than that at $30^{\circ} \mathrm{C}$, indicating suitable characteristics for ethanol production at high temperatures. Therefore, these findings suggest that the expression of AdhA and AdhB is controlled at the translational or post-translational level, not at the transcriptional level. Alternatively, these proteins may be stable and thus accumulate inside cells.

Z. mobilis AdhB has high specificity for ethanol over acetaldehyde [22] as a substrate [22,25,26], thus, it is thought to be involved in ethanol degradation [22] and may be important for lowering the ethanol level inside cells. Active staining experiments indicated that the AdhB activity significantly increased in the stationary phase, where ethanol was accumulated. The increase in AdhB activity is reasonable in respect to its physiological function. However, neither an increase in ethanol nor a decrease in glucose seems to induce the $a d h B$ expression (Fig. 3). The regulation of $a d h B$, which has not been fully defined, seems to be unique and different from $S$. cerevisiae $A D H 2$ [27] or Kluyveromyces marxianus $A D H 4$ [28], which are repressed by glucose and induced by ethanol, respectively, and proposed to be involved in ethanol degradation. Z. mobilis AdhA appears to mainly perform ethanol synthesis [22,25]. The AdhA is like S. cerevisiae Adh1 [29] or K. marxianus Adh1 [28], which are constitutively expressed and are involved in ethanol formation but might have additional regulations responsible for increase in activity in the stationary phase.

\section{ACKNOWLEDGEMENTS}

We thank E. Yanase for providing the Z. mobilis strain. This work was supported by a Grant-in-Aid for Basic Research from the Ministry of Education, Culture, Sports and Science of Japan (to M.Y.) and by the Program for Promotion of Basic Research Activities for Innovative Biosciences (PROBRAIN). This work was done by collaboration in a Core University Program between Yamaguchi University and Kasetsart University, which was supported by the Scientific Cooperation Program agreed by the Japan Society for the Promotion of Science (JSPS) and the National Research Council of Thailand (NRCT).

\section{REFERENCES}

[1] Rogers PL, Lee KL, Tribe DE. High productivity ethanol fermentations with Zymomonas mobilis. Process Biochemistry 1980; 15(6): 7-11.

[2] Swings J, De Ley J. The biology of Zymomonas. Bacteriol Rev 1977; 41(1): 1-46.

[3] Sprenger GA. Carbohydrate metabolism in Zymomonas mobilis : a catabolic highway with some scenic routes. FEMS Microbiol Lett 1996; 145: 301-7.

[4] Barnell WO, Yi KC, Conway T. Sequence and genetic organization of a Zymomonas mobilis gene cluster that encodes several enzymes of glucose metabolism. J Bacteriol 1990; 172(12): 7227-40.

[5] Seo J-S, Chong H, Park HS, et al. The genome sequence of the ethanologenic bacterium Zymomonas mobilis ZM4. Nat Biotechnol 2005; 23(1): 63-8.

[6] Fuhrer T, Fischer E, Sauer U. Experimental identification and quantification of glucose metabolism in seven bacterial species. $\mathrm{J}$ Bacteriol 2005; 187(5): 1581-90.

[7] Barbosa MdFS, Ingram LO. Expression of the Zymomonas mobilis alcohol dehydrogenase II $(a d h B)$ and pyruvate decarboxylase $(p d c)$ genes in Bacillus. Curr Microbiol 1994; 28(5): 279-82.

[8] Gold RS, Meagher MM, Tong S, et al. Cloning and expression of the Zymomonas mobilis "Production of Ethanol" genes in Lactobacillus casei. Current Microbiol 1996; 33(4): 256-60.

[9] Ingram LO, Conway T, Clark DP, et al. Genetic engineering of ethanol production in Escherichia coli. Appl Environ Microbiol 1987; 53(10): 2420-5.

[10] Ingram LO, Aldrich HC, Borges AC, et al. Enteric bacterial catalysts for fuel ethanol production. Biotechnol Prog 1999; 15: 85566.

[11] Thanonkeo P, Laopaiboon P, Sootsuwan K, et al. Magnesium ions improve growth and ethanol production of Zymomonas mobilis under heat or ethanol stress. Biotechnol Bioengineer 2007; 6(1): 1129.

[12] Adachi O, Tayama K, Shinagawa K, Matsushita K, et al. Purification and characterization of particulate alcohol dehydrogenase from Gluconobacter suboxydans. Agric Biol Chem 1978; 42: 2045-56.

[13] Michel G, Azoulay T, Starka J. Ethanol effect on the membrane protein pattern of Zymomonas mobilis. Ann Inst Pasteur Microbiol 1985; 136: 173-9.

[14] Taherzadeh MJ, Eklund R, Gustafsson L, et al. Characterization and fermentation of dilute-acid hydrolyzates from wood. Ind Eng Chem Res 1997; 36: 4659-65.

[15] Sambrook J, Russell DW. Molecular Cloning: A Laboratory Manual: Cold Spring Harbour, 2001.

[16] Sanger F, Nicklen S, Coulson AR. DNA sequencing with chainterminating inhibitors. Proc Natl Acad Sci USA 1977; 74: 5463-7. 
[17] Aiba H, Adhya S, de Crombrugghe B. Evidence for two functional gal promoters in intact Escherichia coli cells. J Biol Chem 1981; 256: 11905-10.

[18] Thein SL, Wallace RB. The use of synthetic oligonucleotides as specific hybridization probes in the diagnosis of genetic disorders. In: Davis KE, editor. Human Genetic Distances: A Practical Approach. Herndon: 1986. pp. 33-50.

[19] Nitta T, Nagamitsu H, Murata M, et al. Function of the $\sigma^{\mathrm{E}}$ regulon in dead-cell lysis in stationary phase Escherichia coli. J Bacteriol 2000; 182: 5231-7.

[20] Kabir MS, Yamashita D, Koyama S, et al. Cell lysis directed by $\sigma^{\mathrm{E}}$ in early stationary phase and effect of induction of the rpoE gene on global gene expression in Escherichia coli. Microbiology 2005; 151(8): 2721-35.

[21] Dulley J, Grieve P. A simple technique for eliminating interference by detergents in the Lowry method of protein determination. Anal Biochem 1975; 64: 136-41.

[22] Neale AD, Scopes RK, Kelly JM, et al. The two alcohol dehydrogenases of Zymomonas mobilis: purification by differential dye ligand chromatography, molecular characterization and physiological roles. Eur J Biochem 1986; 154: 119-24.

[23] Fowler PW, Ball AJ, Griffiths DE. The control of alcohol dehydrogenase isozyme synthesis in Saccharomyces cerevisiae. Canad J Biochem 1972; 50(1): 35-43.
[24] Seymour JL, Lazarus RA. Native gel activity stain and preparative electrophoretic method for the detection and purification of pyridine nucleotide-linked dehydrogenases. Anal Biochem 1989; 178(2): 243-7.

[25] Kinoshita S, Kakizono T, Kadota K, Das K, Taguchi H. Purification of two alcohol dehydrogenases from Zymomonas mobilis and their properties. Appl. Microbiol. Biotechnol. 1985; 22: 249-54.

[26] Willis C, Kratofil P, Londo D, et al. Characterization of the two alcohol dehydrogenases of Zymomonas mobilis. Arhc Biochem Biophys 1981; 210: 775-85.

[27] Ciriary M. Genetics of alcohol dehydrogenase in Saccharomyces cerevisiae. II. Two loci controlling synthesis of the glucoserepressible ADHII. Mol Gen Gent 1975; 138: 157-64.

[28] Lertwattanasakul N, Sootsuwan K, Limtong S, et al. Comparison of the gene expression patterns of alcohol dehydrogenase isozymes in the thermotolerant yeast Kluyveromyces marxianus and their physiological functions. Biosci Biotechnol Biochem 2007; 71(5): 1170-82.

[29] Bennetzen JL, Hall BD. The primary structure of the Saccharomyces cerevisiae gene for alcohol dehydrogenase I. J Biol Chem 1982; 257: 3018-25. 